\title{
GEOMETRICAL ANALYSIS OF PROFILE OF CERTAIN HEAVY TERRAIN SECTIONS EXERTING DYNAMIC LOADS ON THE CHASSIS COMPONENTS OF OFF-ROAD VEHICLES
}

\section{ANALIZA GEOMETRII PROFILU WYBRANYCH ODCINKÓW DRÓG POLIGONOWYCH JAKO ŹRÓDEA OBCIĄŻEŃ DYNAMICZNYCH ELEMENTÓW UKŁADU JEZDNEGO POJAZDÓW TERENOWYCH}

\author{
Witold Luty, Marcin Mieteń \\ Military Institute of Armored and Automotive Technology
}

\begin{abstract}
The paper presents the results of measurements concerned with the changes of profile height observed on selected heavy terrain road sections. Based on the results of direct measurements, primary indicators and amplitude frequency characteristics have been determined. The characteristics of these roads profiles have been presented as a function of path frequency, and also as a function of the vehicle wheels' excitation frequency observed while driving at a certain, constant speed. The results presented serve as a source of information on specific heavy terrain road sections exerting dynamic loads on the vehicle's chassis components while driving in off-road conditions.
\end{abstract}

Keywords: off-road vehicles, heavy terrain roads

Streszczenie: W pracy przedstawiono wyniki pomiaru zmian wysokości profilu wybranych dróg poligonowych. Na podstawie wyników pomiaru bezpośredniego określono podstawowe wskaźniki i charakterystyki częstotliwościowe profilu tych dróg. Charakterystyki przedstawiono $w$ funkcji częstotliwości drogowej oraz częstotliwości oddziaływania na koła jezdne pojazdu podczas jazdy z ustalona prędkościa jazdy. Przedstawione wyniki badań niosa ze soba informacje o charakterze wymuszenia kinematycznego pracy zawieszenia pojazdu podczas jazdy w warunkach terenowych. Pokazano specyfikę tego wymuszenia jako źródto narażenia elementów układu jezdnego pojazdu na udary i przeciązenia podczas jazdy w warunkach terenowych.

Slowa kluczowe: pojazdy terenowe, drogi poligonowe 
Geometrical analysis of profile of certain heavy terrain sections....

Analiza geometrii profilu wybranych odcinków dróg poligonowych....

\section{GEOMETRICAL ANALYSIS OF PROFILE OF CERTAIN HEAVY TERRAIN SECTIONS EXERTING DYNAMIC LOADS ON THE CHASSIS COMPONENTS OF OFF-ROAD VEHICLES}

\section{Introduction}

Reliability of any given vehicle is determined by the structure and by the frequency of undulations of the road surface the vehicle is moving on. Due to the fact that the properties of heavy terrain roads differ from those of paved surfaces, off-road driving causes specific types of loads exerted on the chassis elements. Determination of the impact that the surface exerts on the vehicle driving in off-road conditions requires that an analysis of the off-road surface geometry be conducted. It is a well-known fact that the amplitude of terrain road profile changes may be rather substantial. However, a considerable length along which off-road undulations are stretching results in the fact that, in most cases, the dynamic loads exerted on the vehicle's road wheels are not considerable.

Bibliography fails to provide information on the nature of the impact that off-road conditions exert on the vehicle. In most cases, while assessing the road surface profile changes, statistical indicators are given. The RMS of the road surface profile changes is among the most popular indicators used for comparison purposes [1-5,8]. Amplitude and frequency characteristics, as well as the power spectral density (PSD) also serve as important indicators describing road profile changes $[3,5-7,9,10]$. Such characteristics serve as a source of information on the level and frequency structure of the dynamic loads to which the vehicle's chassis components are subjected to while driving in off-road conditions. While testing off-road vehicles in real life conditions, a need arises to determine the specific parameters of terrain road surfaces in order to:

- perform the tests in repeatable conditions,

- to ensure that the dynamic loads exerted match the requirements,

- to establish the degree of similarity or dissimilarity between test road surfaces and surfaces available at other off-road facilities.

Hence, the idea was born to measure and evaluate the profile of off-road surfaces available at the test facility.

\section{Research problem and test method}

The measurements were taken along different sections of the terrain roads available on the premises of the Armored and Automotive Technology Institute's test track in Sulejówek. The description of the individual sections is presented in Table 2. The individual sections have been selected as representative for the remaining tank test track facilities of the Armored and Automotive Technology Institute. It is obvious at first sight that the surface sections selected differ in terms of the amplitude and length of undulations. 
Tab. 2. Description of the heavy terrain road sections analyzed

\begin{tabular}{|c|c|c|}
\hline $\begin{array}{c}\text { Surface type } \\
\text { designation }\end{array}$ & View of the section & Primary features \\
\hline S1 - dirt road & & $\begin{array}{l}\text { - sandy dirt road, compacted } \\
\text { - no or shallow ruts created } \\
\text { by road wheels } \\
\text { - undulations of considerable } \\
\text { length exceeding the } \\
\text { vehicle's wheel base }\end{array}$ \\
\hline $\begin{array}{l}\text { S2 - tank road, } \\
\text { light }\end{array}$ & & $\begin{array}{l}\text { - sandy dirt road, loose } \\
\text { - ruts created by road } \\
\text { wheels may be present } \\
\text { - undulations of length } \\
\text { exceeding the vehicle's } \\
\text { wheel base }\end{array}$ \\
\hline $\begin{array}{l}\text { S3 - tank road, } \\
\text { heavy }\end{array}$ & & $\begin{array}{l}\text { - sandy dirt road, loose } \\
\text { - deep ruts created by road } \\
\text { wheels } \\
\text { - undulations of length } \\
\text { comparable to the } \\
\text { vehicle's wheel base }\end{array}$ \\
\hline
\end{tabular}

The changes in the profile height of terrain surfaces were measured during the tests. The profile height changes were measured by means of the direct method, with the help of a total station (Fig. 1) and a leveling rod with a scale. The profile height changes were measured inside the ruts created by the wheels of vehicles passing before the measurement. Such a method enabled the authors to measure the effective profile, i.e. the one that was tracked by the wheels of the vehicle. It was characterized by a permanent plastic deformation and was smoothed by tire pressure. The measurement points were spread every $20 \mathrm{~cm}$ along the vehicle's track. Such a distance is sufficient to the smoothing effect of the vehicle's tires. 
Geometrical analysis of profile of certain heavy terrain sections.... Analiza geometrii profilu wybranych odcinków dróg poligonowych....

The leveling rod was positioned vertically at each of those points, and the height of the specific point was measured on the rod and compared with the vertical position of the total station head. Measurement results reflected the changes in the profile along the ruts.

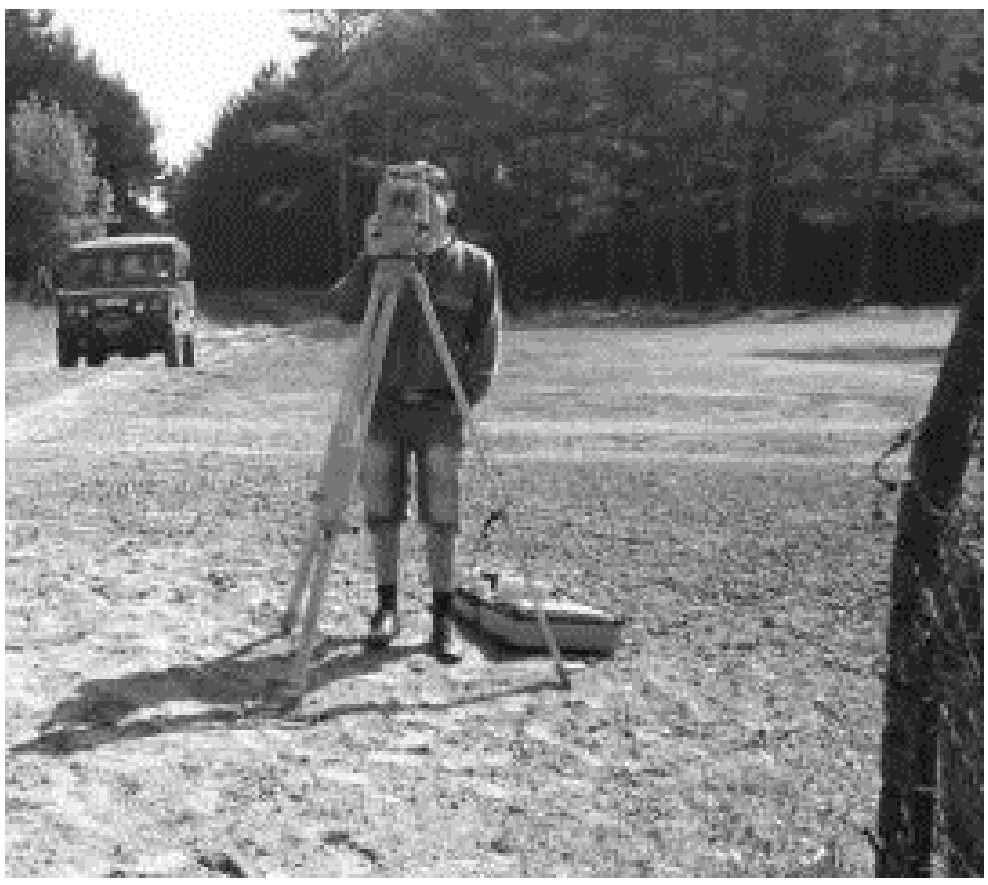

Fig. 1 Measuring instrument used during the test

\section{Measurement and calculation results}

The measurement results are presented as a function of distance (Fig. 2.). Based on the profile height changes, the following have been determined:

- effective RMS values (Fig. 3)

- amplitude and frequency characteristics A-Cz (Fig. 4),

- power spectral density characteristics PSD (Fig. 5).

The characteristics measured make it possible to describe the changing nature of the individual sections of the heavy terrain road, exerting a dynamic load on the wheels of the vehicle and resulting in the degradation of its load-bearing structure. Changes in the profile height of the off-road sections analyzed are specified without the longitudinal inclination taken into consideration. Such an approach eliminates, from the profile characteristics, peak points with the frequency close to 0 , but does not alter the results concerning the frequencies that are crucial for vibrations and shocks caused by surface roughness. The density of individual characteristics is presented in $1 \mathrm{~m}$ intervals. 
This means that the density of amplitude or profile height change changes is presented per 1 meter of distance covered.

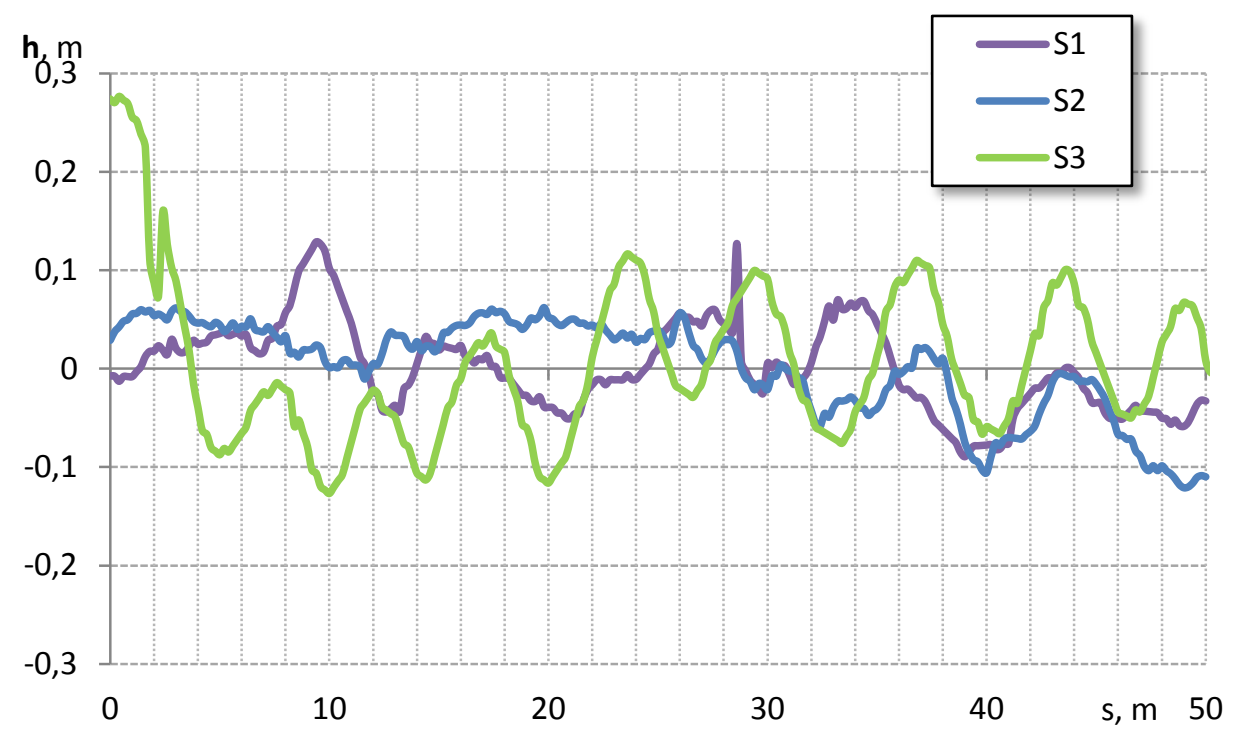

Fig. 2. Changes in the profile height of the off-road sections analyzed

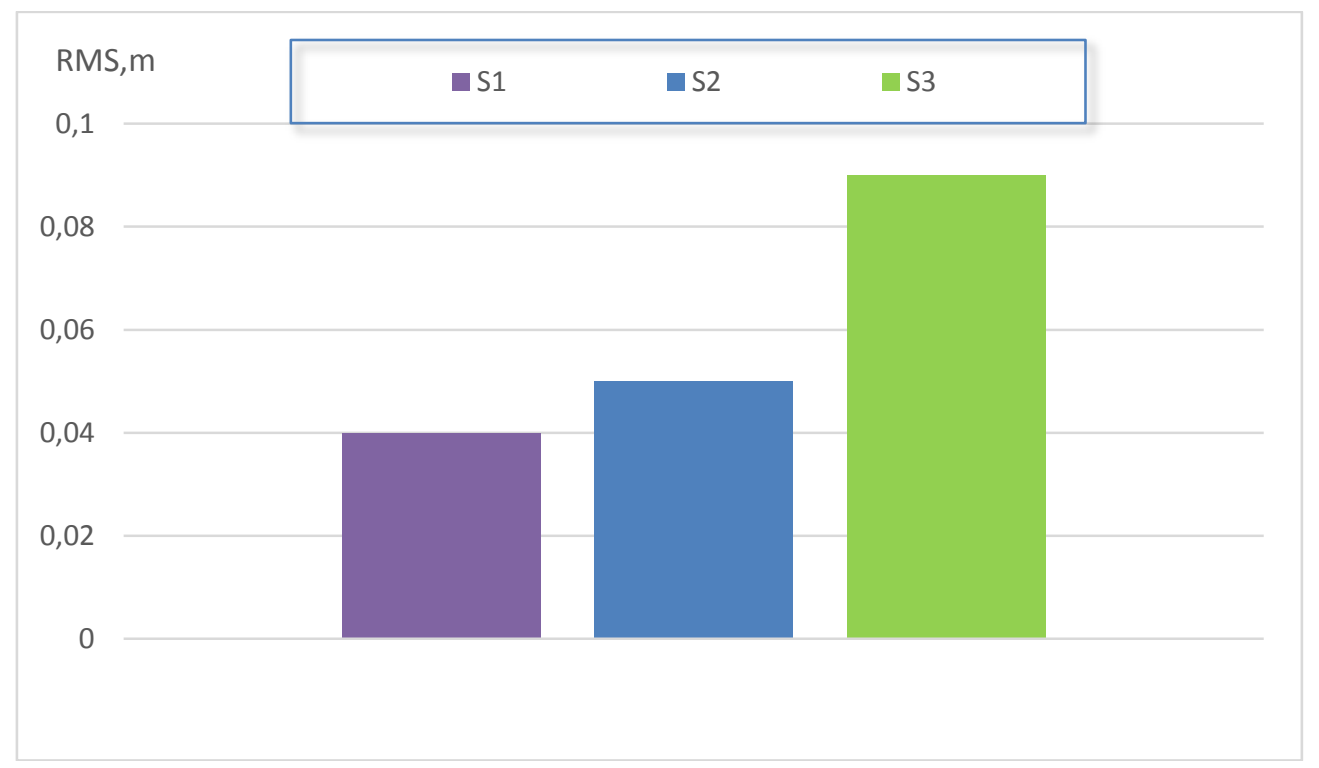

Fig. 3. Comparison of RMS values corresponding to profile height changes of the off-road sections analyzed 
Geometrical analysis of profile of certain heavy terrain sections.... Analiza geometrii profilu wybranych odcinków dróg poligonowych....

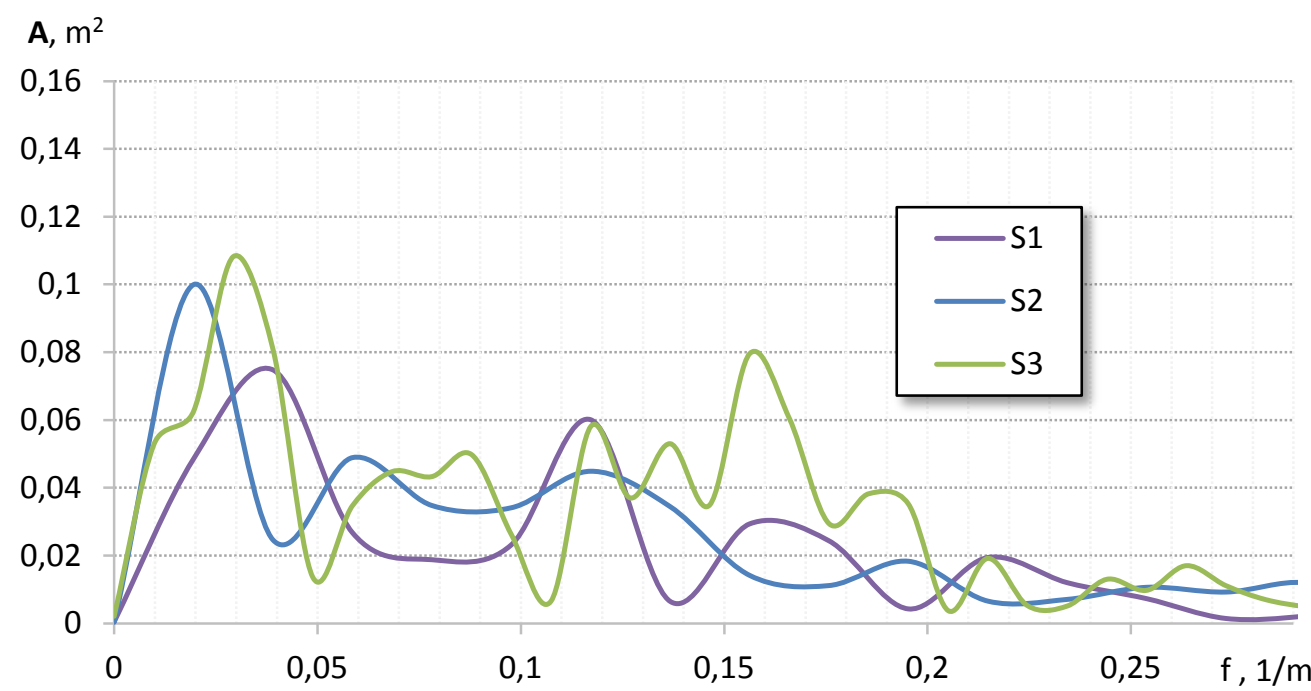

Fig. 4. Comparison of amplitude and frequency characteristics of the profile of the off-road sections tested

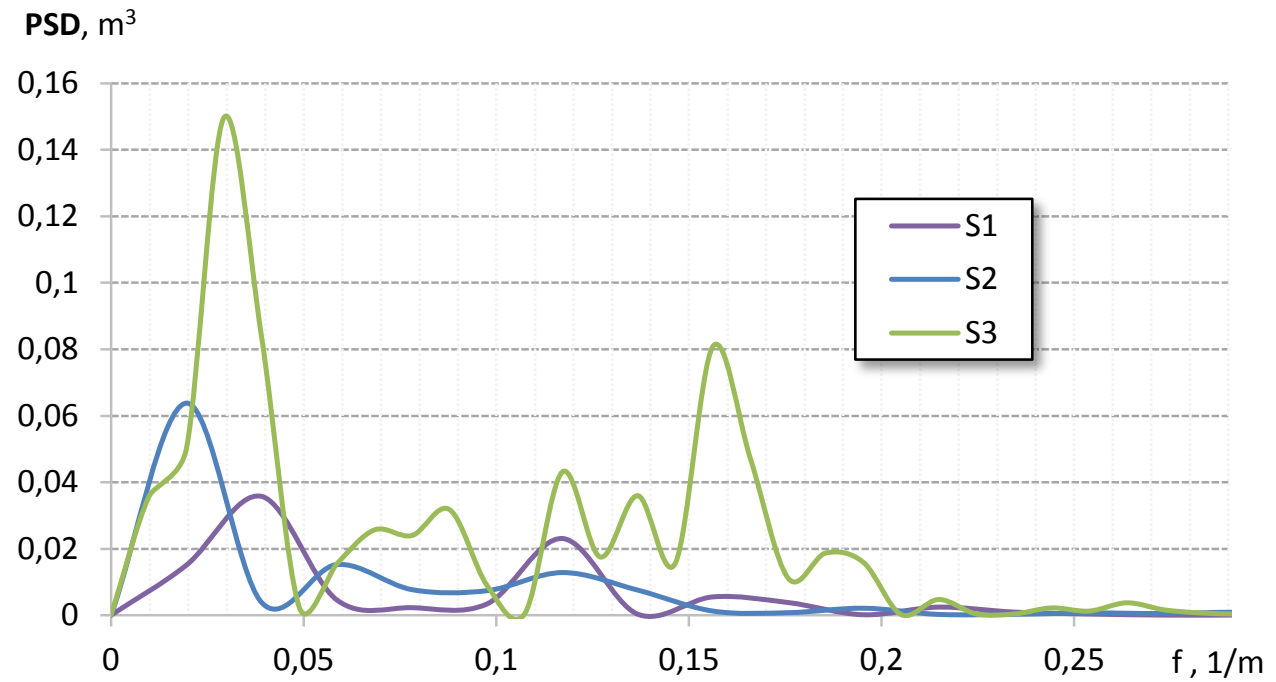

Fig. 5. Power spectral density characteristics relevant for changes in the profile height of off-road sections analyzed

The characteristics presented may be converted into the corresponding chassis deflection frequency $(\mathrm{Hz})$ after taking into consideration the speed at which the vehicle is moving along the specific type of surface. 
That is how characteristics of the road wheels' deflection may be obtained while driving at a specific speed. Examples of such characteristics measured for the driving speeds of $v=12 \mathrm{~km} / \mathrm{h}$ and $v=24 \mathrm{~km} / \mathrm{h}$ are presented in Figures 6-9.

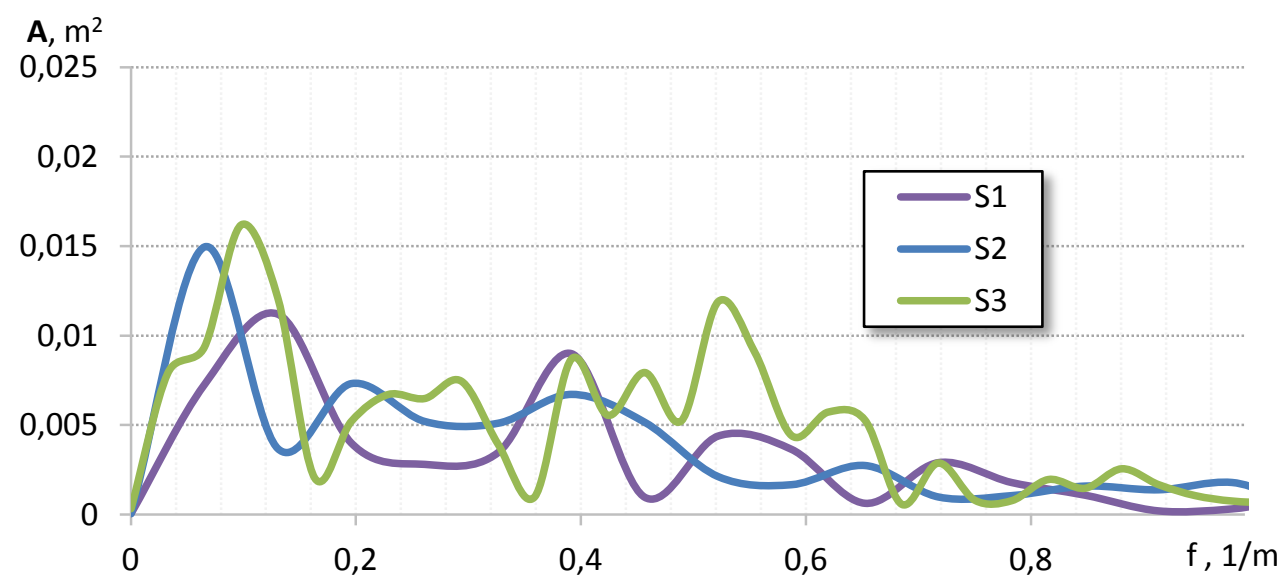

Fig. 6. Amplitude and frequency characteristics of vehicle wheel deflections while driving along the off-road test sections with the speed of $V=12 \mathrm{~km} / \mathrm{h}$

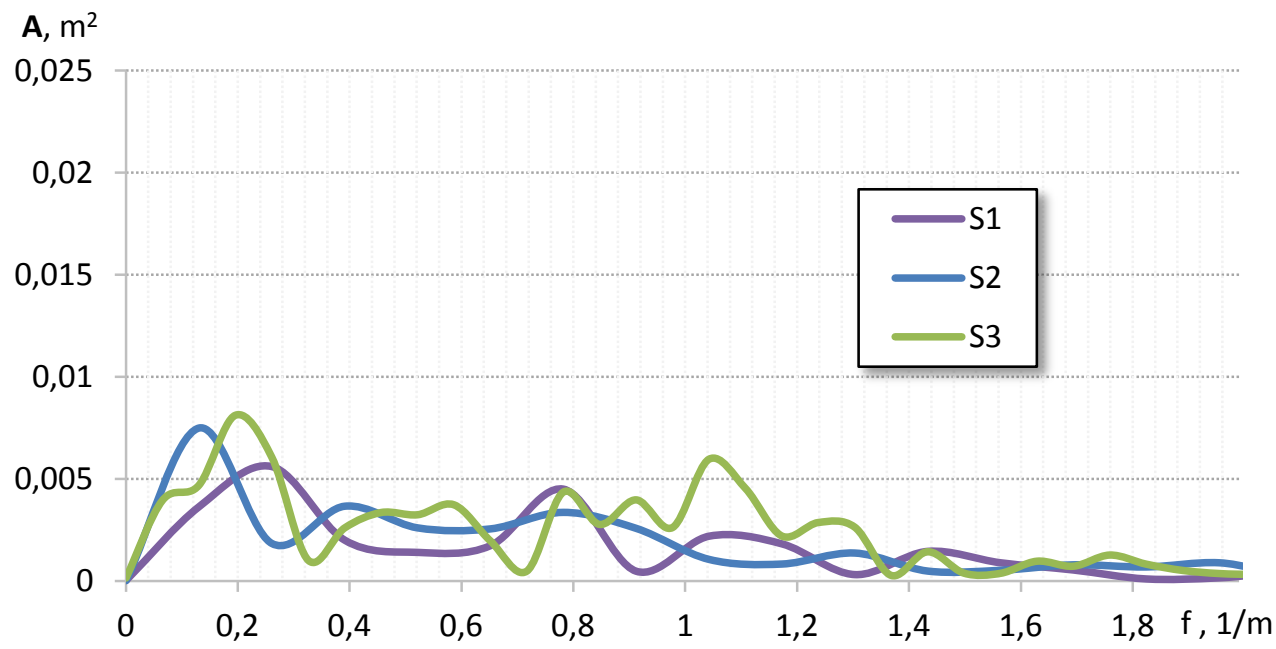

Fig. 7. Amplitude and frequency characteristics of vehicle wheel deflections while driving along the off-road test sections with the speed of $V=24 \mathrm{~km} / \mathrm{h}$

The direct measurement results have rendered similar RMS values for S1 and S2 off-road sections, despite the fact that the roughness amplitude of the S2 road seems to be much higher (based on visual assessment) than that of the S1 section (Tab. 1, Fig. 2). 
Geometrical analysis of profile of certain heavy terrain sections.... Analiza geometrii profilu wybranych odcinków dróg poligonowych....

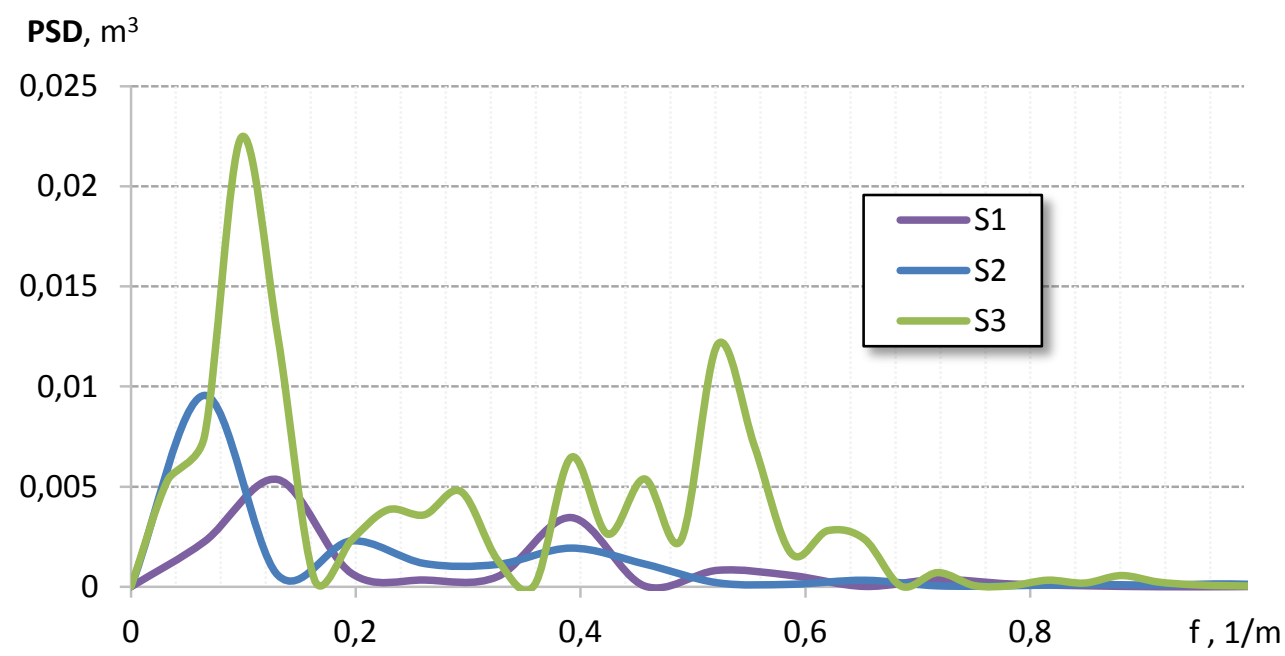

Fig. 8. Power spectral density characteristics of vehicle wheel deflections while driving along the off-road test sections with the speed of $V=12 \mathrm{~km} / \mathrm{h}$

PSD, $\mathrm{m}^{3}$

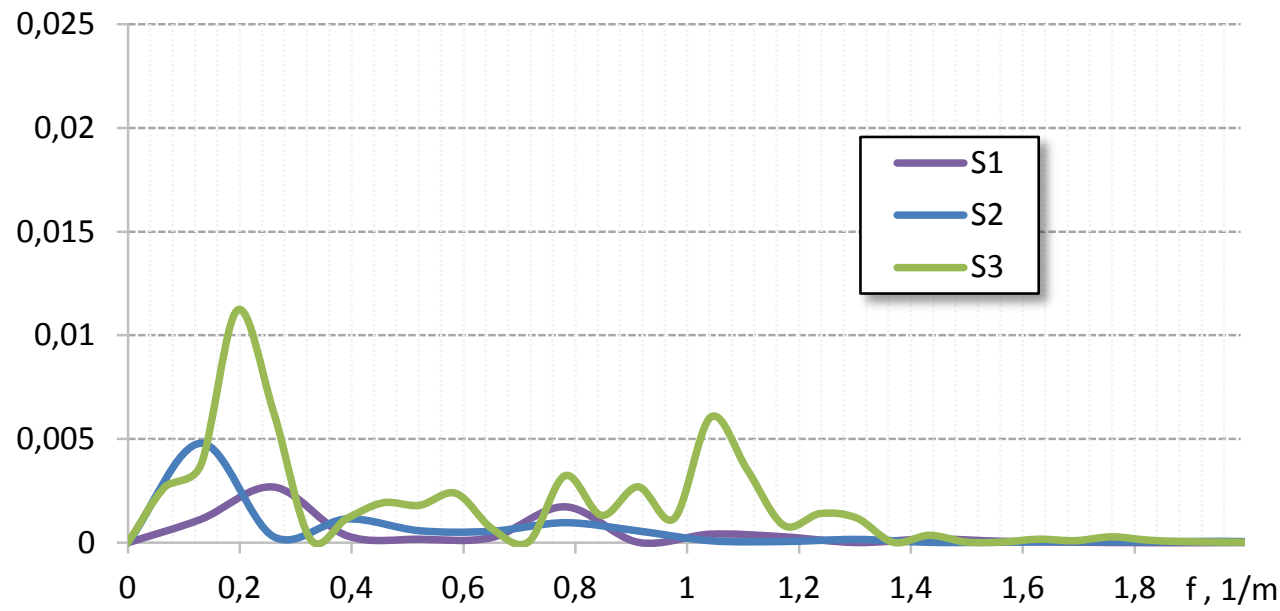

Fig. 9. Power spectral density characteristics of vehicle wheel deflections while driving along the off-road test sections with the speed of $V=24 \mathrm{~km} / \mathrm{h}$

The spectral characteristics show that the harmonic component of the S2 profile roughness change is clearly higher than that of the S1 section, as far as the road frequency of up to approx. $0.051 / \mathrm{m}$ is concerned. Within that road frequency range, the roughness length exceeds $20 \mathrm{~m}$. Hence, the impact thereof on the dynamic loads borne by the vehicle's chassis elements is negligible, especially while driving at slow speeds that are typical for off-road conditions. 
The S1 off-road section, in turn, is characterized by much higher spectral values that in the case of the S2 section, as far as the higher road frequencies are concerned (e.g. approx. 0.12, 0.16 and $0.221 / \mathrm{m}$ ). Hence, the S1 profile has a number of shorter undulations up to approx. $4.5 \mathrm{~m}$ long, and with their amplitude higher than in the case of the S2 section. As a result, with the comparable RMS values of the profile height changes observed in both sections, the dynamic loads exerted on the road wheels of the vehicle differ in terms of the amplitude and frequency values.

The S2 off-road section is characterized by a much higher profile change RMS value compared to the other sections tested. However, in this specific case, the higher profile height change amplitude values are higher than the amplitudes observed on the remaining types of surfaces, as far as both the lowest and the highest values of road frequencies analyzed are concerned.

The profile characteristics of the selected off-road sections indicate that unpaved surfaces are of a very peculiar character. From the point of view of the length of undulations (up to approx. $0.31 / \mathrm{m}$ ) such surfaces are categorized (in the classification of paved surfaces) as "even" [5]. Hence, one should consider this type of surface to be of the best quality. However, unpaved surfaces are characterized by a much higher amplitude of their profile changes than it is the case with high quality paved surfaces. Therefore, dirt surfaces should not be evaluated based on the same criteria as applied to paved roads.

All off-road sections tested cause low-frequency road wheel vibrations while driving at the speeds that are achievable in off-road conditions (Fig. 6-9). The majority of road wheel vibrations caused by dynamic loads exerted by road surface undulations have the frequency of $\mathrm{f}=0.7 \mathrm{~Hz}$ while driving with the speed of 12 $\mathrm{km} / \mathrm{h}$ to $\mathrm{f}=1.4 \mathrm{~Hz}$ while driving with the speed of $24 \mathrm{~km} / \mathrm{h}$. These frequencies are of the sub-resonating variety compared to the frequency of the chassis' own vibrations, typical for an off-road vehicle (approx. 2Hz), and even more so compared to the frequency of the road wheels' own vertical vibrations (from approx. 8 to $10 \mathrm{~Hz}$ ).

\section{Summary}

The test results provide us with knowledge on the geometrical properties of tank road sections, including the frequency structure of the vertical vibrations caused by loads exerted on the road wheels while driving in off-road conditions. The results also serve as a source of data required to simulate the behavior of vehicles driving in off-road conditions.

The results are useful for determining real-life test conditions in which specialpurpose vehicles, especially of the military character, are tested. According to the authors, the results may be used in further research aiming to describe and classify the individual types of off-road test surfaces. Determining the characteristics of individual test sections will make it possible to place the structure and the scope of real-life tests that vehicles undergo during the qualification testing process.

The tests results have indicated that the road profile change RMS value, often relied upon as a comparative indicator, does not serve as a fully reliable basis for comparing different off-road sections that generate various levels of road wheel vibrations and shocks while driving in off-road conditions. The frequency structure of the off-road section's profile is an important element of its overall characteristics. 
Geometrical analysis of profile of certain heavy terrain sections....

Analiza geometrii profilu wybranych odcinków dróg poligonowych....

\section{References}

[1] Endurance testing of tracked and wheeled vehicles. U.S. Army Test and Evaluation Command, Aberdeen Proving Ground, Maryland, 26 June 81, AD-A102 584.

[2] Dawkins J. J.: Terrain Characterization and Roughness Estimation for Simulation and Control of Unmanned Ground Vehicles. Auburn, Alabama 2011.

[3] Jacenko N.: Drgania, wytrzymałość i przyspieszone badania samochodów ciężarowych. WKiŁ, Warsaw 1975.

[4] Johannesson P., Podgórski K.: Modelling roughness of road profiles on parallel tracks using roughness indicators. Matematiska vetenskaper 2014.

[5] Loprencipe G., Cantisani G.: Unified Analysis of Road Pavement Profiles for Evaluation of Surface Characteristics. Modern Applied Science; Vol. 7, No. 8; 2013, ISSN 1913-1844 E-ISSN 1913-1852, Published by Canadian Center of Science and Education.

[6] Ojeda L., Borenstein J.: Terrain Characterization and Classification with a Mobile Robot. Journal of Field Robotics 2006.

[7] Patel C. B., Gohil P. P.: Modelling and vibration analysis of a road profile measuring system. International Journal of Automotive and Mechanical Engineering 2010.

[8] Test Operations Procedure (TOP) 01-1-011A Vehicle Test Facilities at Aberdeen Test Center and Yuma Test Center. US Army Aberdeen Test Center, Aberdeen Proving Ground, MD, 27-02-2012.

[9] Kasprzak T., Prochowski L.: Obciążenia dynamiczne zawieszeń, WKiŁ, Warsaw 1990.

[10] Mitschke M.: Dynamika samochodu, WKiŁ, Warsaw 1977.

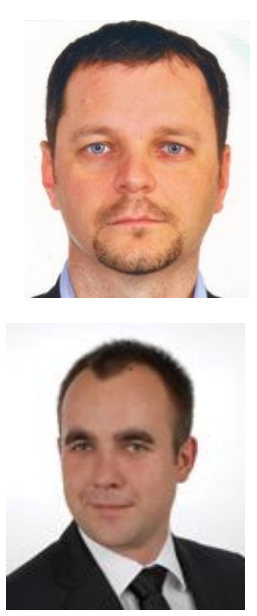

Witold Luty PhD. Eng. - Military Institute of Armored and Automotive Technology Wheeled Vehicles Department Armored Vehicle Laboratory (Share 50\%)

Marcin Mieteń MSc. Eng. - Military Institute of Armored and Automotive Technology Wheeled Vehicles Department Armored Vehicle Laboratory (Share 50\%) 


\section{ANALIZA GEOMETRII PROFILU WYBRANYCH ODCINKÓW DRÓG POLIGONOWYCH JAKO ŹRÓDŁA OBCIĄŻEŃ DYNAMICZNYCH ELEMENTÓW UKLADU JEZDNEGO POJAZDÓW TERENOWYCH}

\section{Wstęp}

Niezawodność pojazdu jest zdeterminowana poziomem i strukturą częstotliwościową oddziaływania nierówności podłoża po jakim się porusza. Jazda pojazdu w warunkach terenowych charakteryzuje się specyficznymi warunkami wymuszenia, ze względu na właściwości podłoża odmienne od podłoży utwardzonych. Określenie charakteru oddziaływania podłoża gruntowego na pojazd podczas jazdy wymaga przeprowadzenia analizy geometrii podłoża gruntowego. Wiadomo, że amplitudy zmian profilu podłoża gruntowego mogą osiągać znaczne wartości. Jednak znaczna długość nierówności podłoży gruntowych sprawia, że częstotliwość wymuszeń kinematycznych działających na koła jezdne pojazdu jest najczęściej niewielka.

W literaturze brakuje informacji na temat charakteru odziaływania podłoży gruntowych na pojazd. Podczas oceny zmian profilu podłoża zazwyczaj podaje się wartości wskaźników statystycznych. Najbardziej popularnym wskaźnikiem porównawczym jest wartość skuteczna RMS zmiany profilu podłoża drogi [1-5,8]. Ważnym narzędziem charakteryzującym zmiany profilu podłoża są charakterystyki amplitudowo częstotliwościowe lub gęstość widmowa mocy (PSD) [3,5-7,9,10]. Takie charakterystyki niosą ze sobą informacje o poziomie oraz strukturze częstotliwościowej wymuszeń kinematycznych działających na koła pojazdu podczas jazdy w warunkach terenowych. W procesie badań pojazdów terenowych metodą przebiegu zachodzi potrzeba parametryzacji profilu podłoży gruntowych w celu:

- ustalenia powtarzalnych warunków badań,

- zgodności charakteru wymuszeń z wymaganiami,

- podobieństwa albo braku podobieństwa profilu podłoży $\mathrm{z}$ podłożami występującymi na innych poligonach badawczych.

Stąd narodziła się potrzeba zmierzenia i oceny profilu odcinków dróg poligonowych występujących w ramach dysponowanego poligonu badawczego.

\section{Problem badawczy i metoda badawcza}

Obiektem badań były różne rodzaje odcinków podłoża gruntowego dostępne na poligonie badawczym WITPiS w Sulejówku. Opis poszczególnych odcinków przestawiono w tabeli 2. Poszczególne odcinki dobrano jako reprezentatywne dla dróg poligonowych WITPiS. Już na pierwszy rzut oka, wybrane odcinki podłoża gruntowego różnią się pod względem wartości amplitudy i długości nierówności. 
Geometrical analysis of profile of certain heavy terrain sections....

Analiza geometrii profilu wybranych odcinków dróg poligonowych....

Tab. 2. Opis badanych odcinków dróg poligonowych

\begin{tabular}{|c|c|c|}
\hline $\begin{array}{l}\text { Oznaczenie } \\
\text { rodzaju } \\
\text { podłoża }\end{array}$ & Widok odcinka & Podstawowe cechy \\
\hline S1-bezdroże & & $\begin{array}{l}\text { - nawierzchnia gruntowa } \\
\text { piaszczysta, ubita } \\
\text { - brak albo płytkie } \\
\text { bruzdowanie przez koła } \\
\text { jezdne pojazdu } \\
\text { - nierówności o znacznej } \\
\text { długości przewyższającej } \\
\text { rozstaw osi pojazdu }\end{array}$ \\
\hline $\begin{array}{l}\text { S2-droga } \\
\text { czołgowa } \\
\text { łagodna }\end{array}$ & & $\begin{array}{l}\text { - nawierzchnia gruntowa } \\
\text { piaszczysta, luźna } \\
\text { - możliwe bruzdowanie } \\
\text { przez koła jezdne pojazdu } \\
\text { - nierówności o długości } \\
\text { przewyższającej rozstaw } \\
\text { osi pojazdu }\end{array}$ \\
\hline $\begin{array}{l}\text { S3-droga } \\
\text { czołgowa } \\
\text { ciężka }\end{array}$ & & $\begin{array}{l}\text { - nawierzchnia gruntowa } \\
\text { piaszczysta, luźna } \\
\text { - głębokie bruzdowanie } \\
\text { przez koła jezdne pojazdu } \\
\text { - nierówności o długości } \\
\text { porównywalnej } \\
\text { z rozstawem osi pojazdu }\end{array}$ \\
\hline
\end{tabular}

Podczas badań zmierzono zmiany wysokości profilu podłoży gruntowych. Zmiany wysokości profilu mierzono metodą pomiaru bezpośredniego za pomocą tachimetru (rys. 1) i łaty niwelacyjnej z podziałką. Zmiany wysokości profilu mierzono $\mathrm{w}$ koleinach które zostały wykonane przez koła przejeżdżającego wcześniej pojazdu. W ten sposób charakterystyce został poddany profil efektywny tzn. taki po którym toczyły się koła pojazdu po trwałym odkształceniu plastycznym i wygładzonym pod naciskiem opon. Na odcinku pomiarowym na śladach zostawionych przez pojazd odmierzano punkty pomiarowe co $20 \mathrm{~cm}$. Taka odległość jest wystarczająca z uwagi na wygładzające działanie śladów ogumienia kół jezdnych pojazdu. W każdym punkcie ustawiano łatę w pozycji pionowej i odczytywano wysokość punktu na łacie względem w pozycji pionowej głowicy tachimetru. Wyniki badań stanowiły przebiegi zmian profilu $\mathrm{W}$ funkcji przemieszczenia wzdłuż koleiny. 


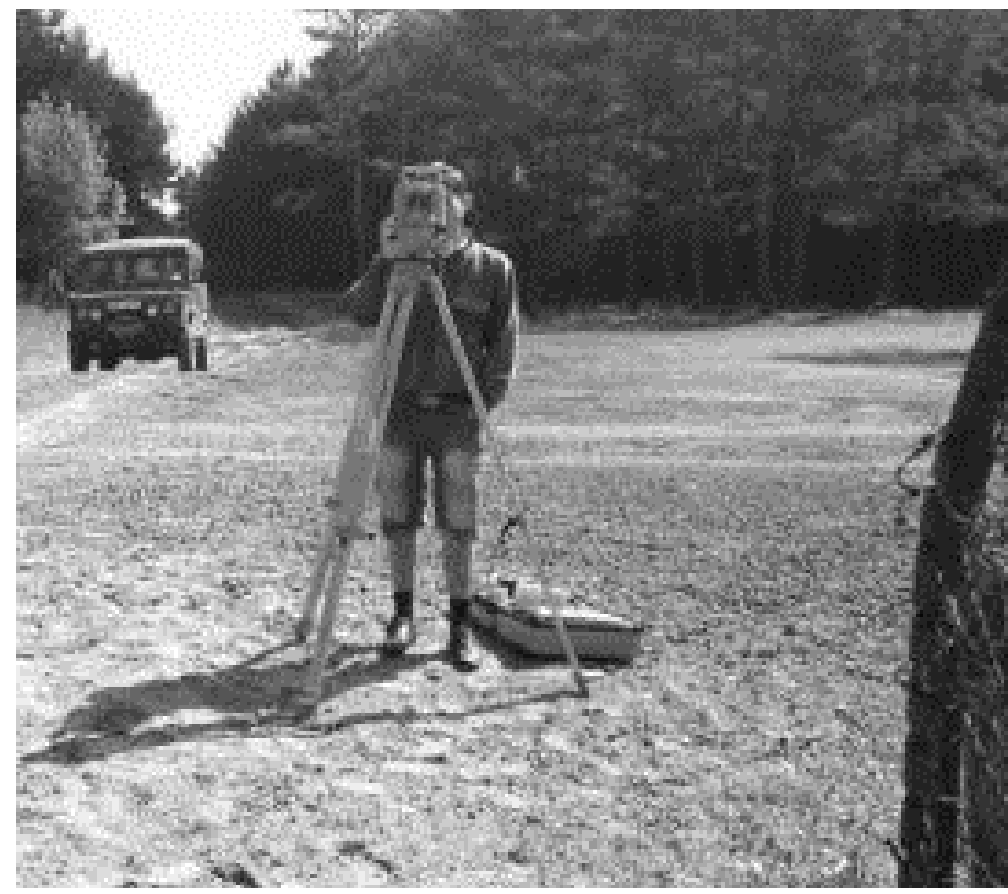

Rys. 1. Widok przyrządu pomiarowego podczas badań

\section{Wyniki pomiarów i obliczeń}

Wyniki pomiaru przedstawiono $\mathrm{w}$ funkcji (rys. 2) dystansu. Na podstawie wyznaczonych przebiegów zmian wysokości poszczególnych profili dróg poligonowych wyznaczono:

- wartości skuteczne RMS, (rys. 3)

- charakterystyki amplitudowo-częstotliwościowe A-Cz (rys. 4),

- charakterystyki gęstości widmowej mocy PSD (rys. 5).

Wyznaczone charakterystyki umożliwiają opisanie zmienności poszczególnych rodzajów podłoża gruntowego jako wymuszenia kinematycznego działającego na koła pojazdu, które jest źródłem degradacji jego struktury nośnej. Przebiegi zmian profilu badanych odcinków dróg poligonowych pozbawiono trendu wynikającego ze pochylenia wzdłużnego terenu. Taka operacja eliminuje z charakterystyk profilu dominanty o częstotliwości bliskiej 0 , ale nie zmienia ich przebiegu $\mathrm{w}$ zakresie częstotliwości istotnych z punktu widzenia narażenia pojazdu na drgania i udary wynikające $\mathrm{z}$ nierówności podłoża. Charakterystyki zostały przedstawione w dziedzinie częstości drogowej $(1 / \mathrm{m})$. Opisują one gęstość rozkładu amplitud lub mocy zmian profilu w przeliczeniu na 1 metr dystansu. 
Geometrical analysis of profile of certain heavy terrain sections.... Analiza geometrii profilu wybranych odcinków dróg poligonowych....

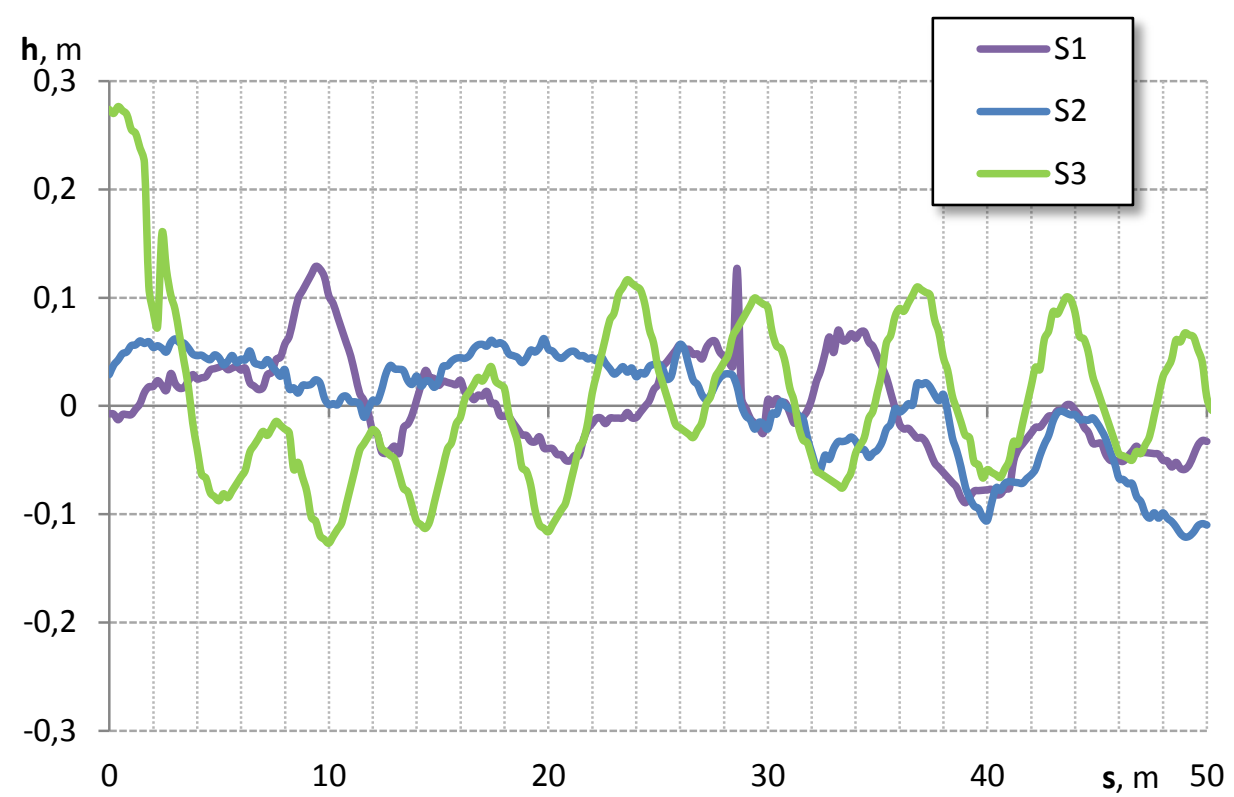

Rys. 2. Przebieg zmian wysokości profilu badanych odcinków dróg poligonowych

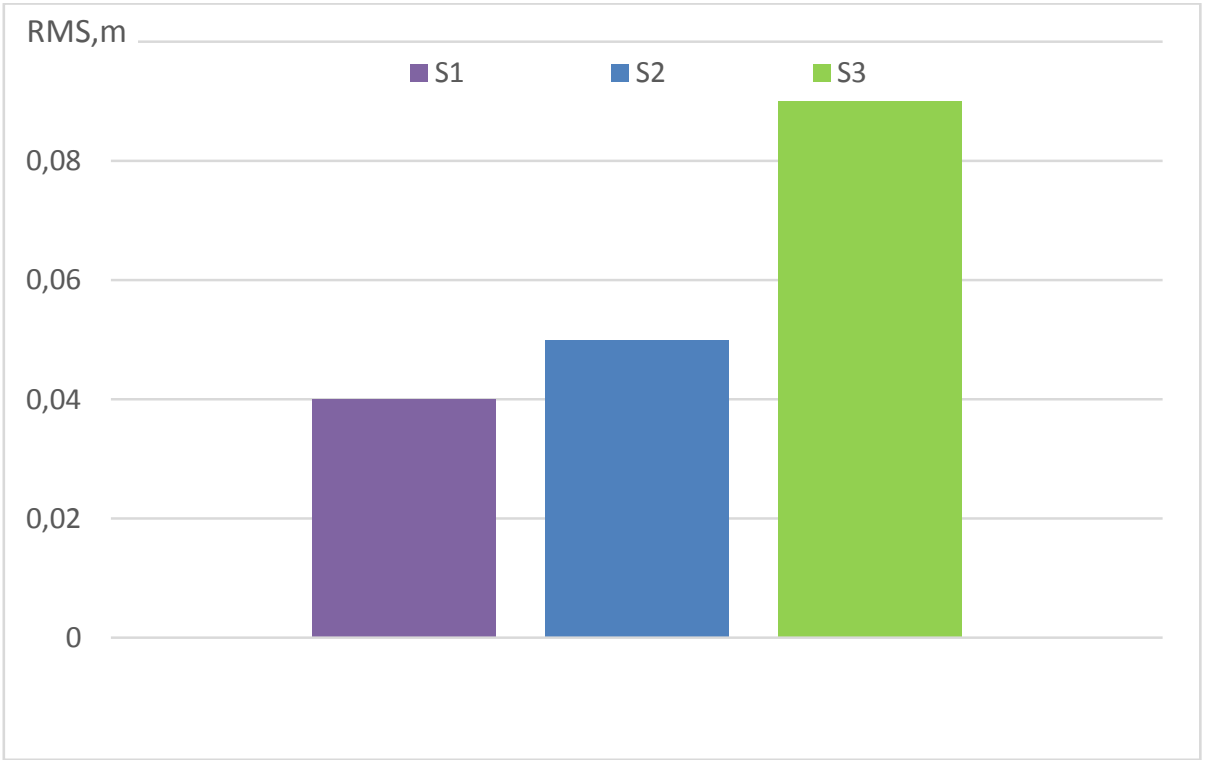

Rys. 3. Zestawienie wartości skutecznych RMS zmian wysokości profilu badanych odcinków dróg poligonowych 


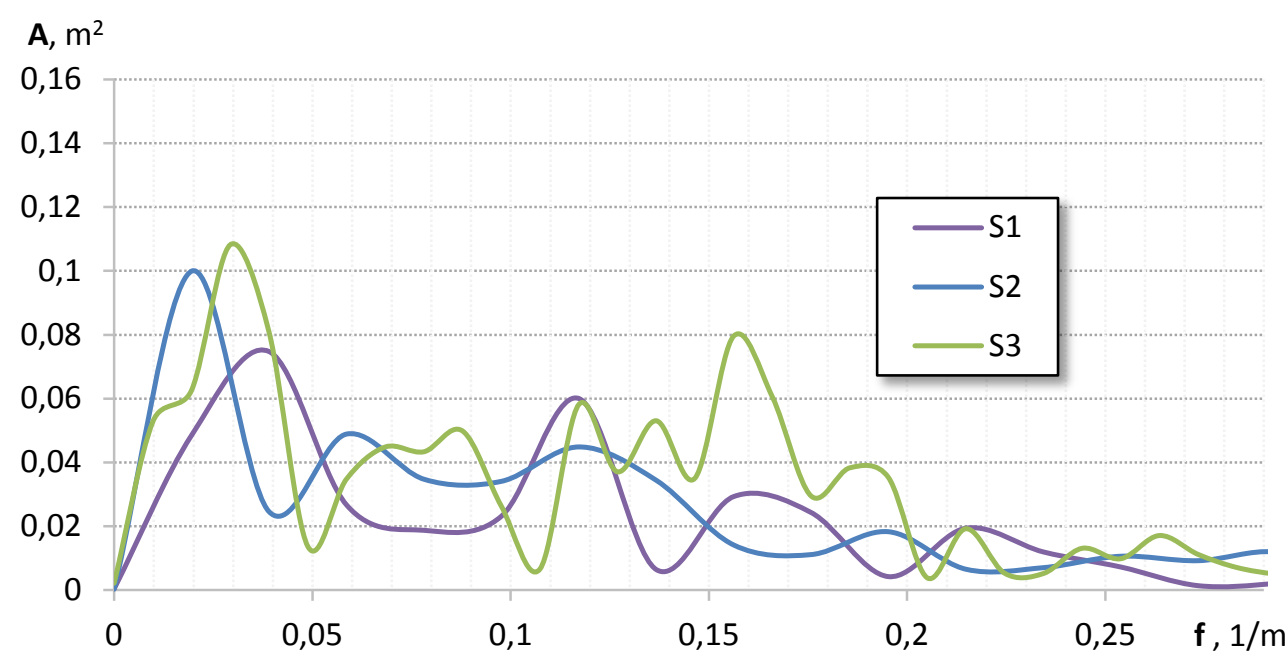

Rys. 4. Zestawienie charakterystyk amplitudowo-częstotliwościowych profilu badanych odcinków dróg poligonowych

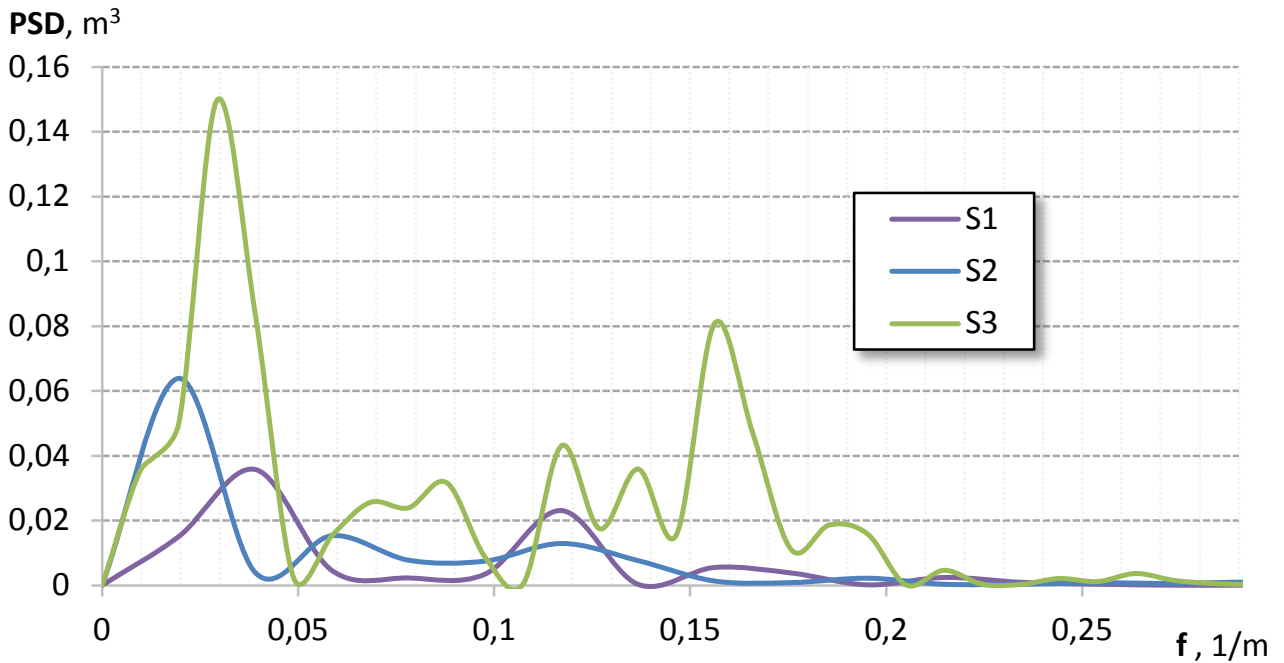

Rys. 5. Zestawienie charakterystyk gęstości widmowej mocy PSD zmian wysokości profilu badanych odcinków dróg poligonowych

Przedstawione charakterystyki mogą być zamienione na ich analogiczną postać w dziedzinie częstotliwości wymuszenia $(\mathrm{Hz})$ po uwzględnieniu prędkości jazdy pojazdu po danym typie podłoża. W ten sposób można uzyskać charakterystyki wymuszenia kinematycznego ruchu kół pojazdu podczas jazdy pojazdu z określoną prędkością. 
Geometrical analysis of profile of certain heavy terrain sections.... Analiza geometrii profilu wybranych odcinków dróg poligonowych....

Przykłady takich charakterystyk wyznaczonych do prędkości jazdy $\mathrm{v}=12 \mathrm{~km} / \mathrm{h}$ i $\mathrm{v}=24 \mathrm{~km} / \mathrm{h}$ przedstawiono na rysunkach $6-9$.

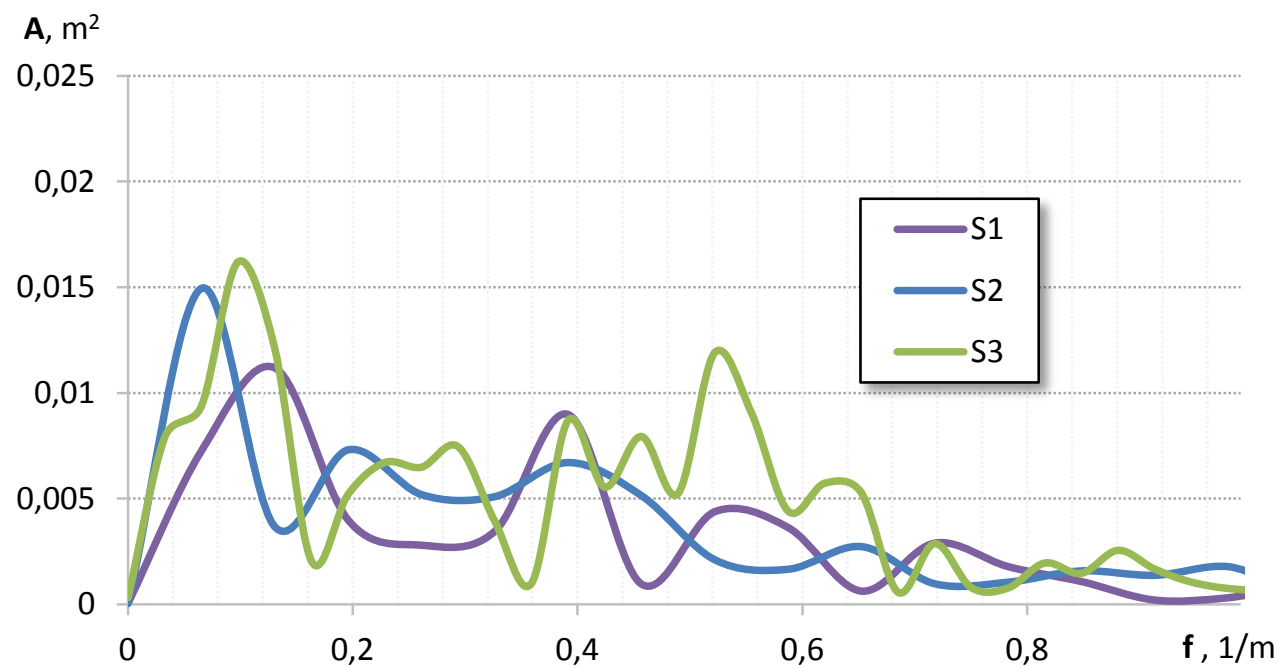

Rys. 6. Zestawienie charakterystyk amplitudowo-czestotliwościowych wymuszenia kinematycznego kót pojazdu podczas jazdy po badanych odcinkach dróg poligonowych z prędkościa $V=12 \mathrm{~km} / \mathrm{h}$

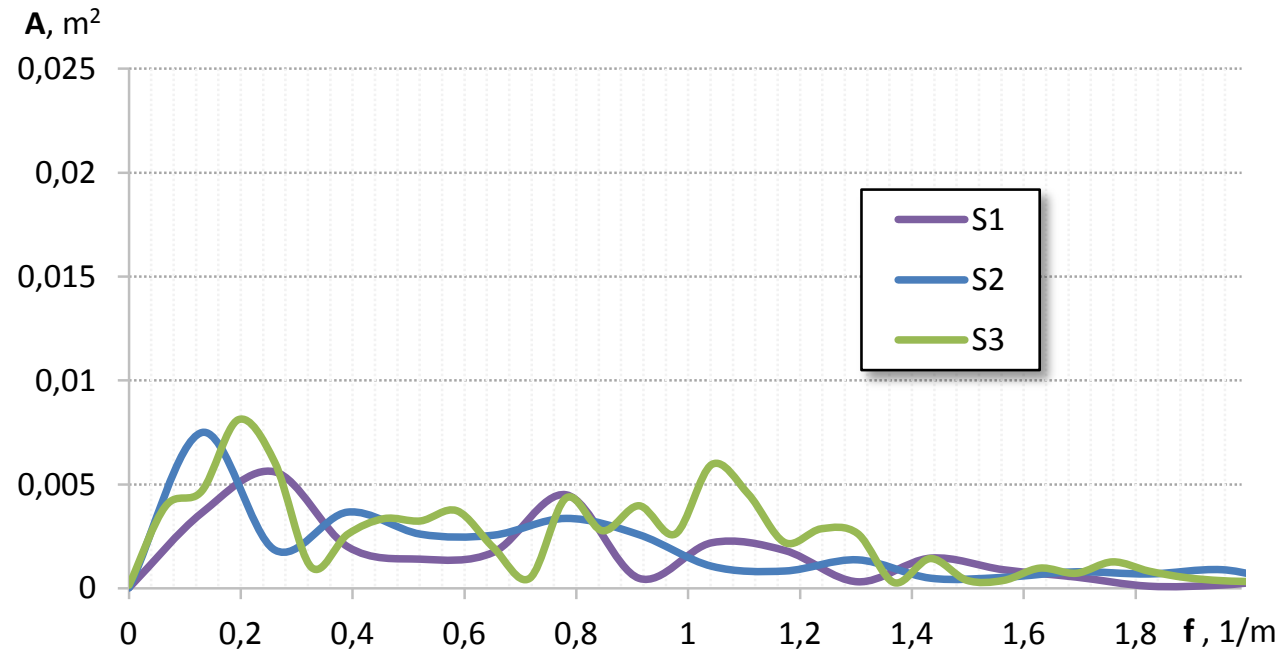

Rys. 7. Zestawienie charakterystyk amplitudowo-częstotliwościowych wymuszenia kinematycznego kót pojazdu podczas jazdy po badanych odcinkach dróg poligonowych z prędkościa $V=24 \mathrm{~km} / \mathrm{h}$ 
Witold Luty, Marcin Mieteń

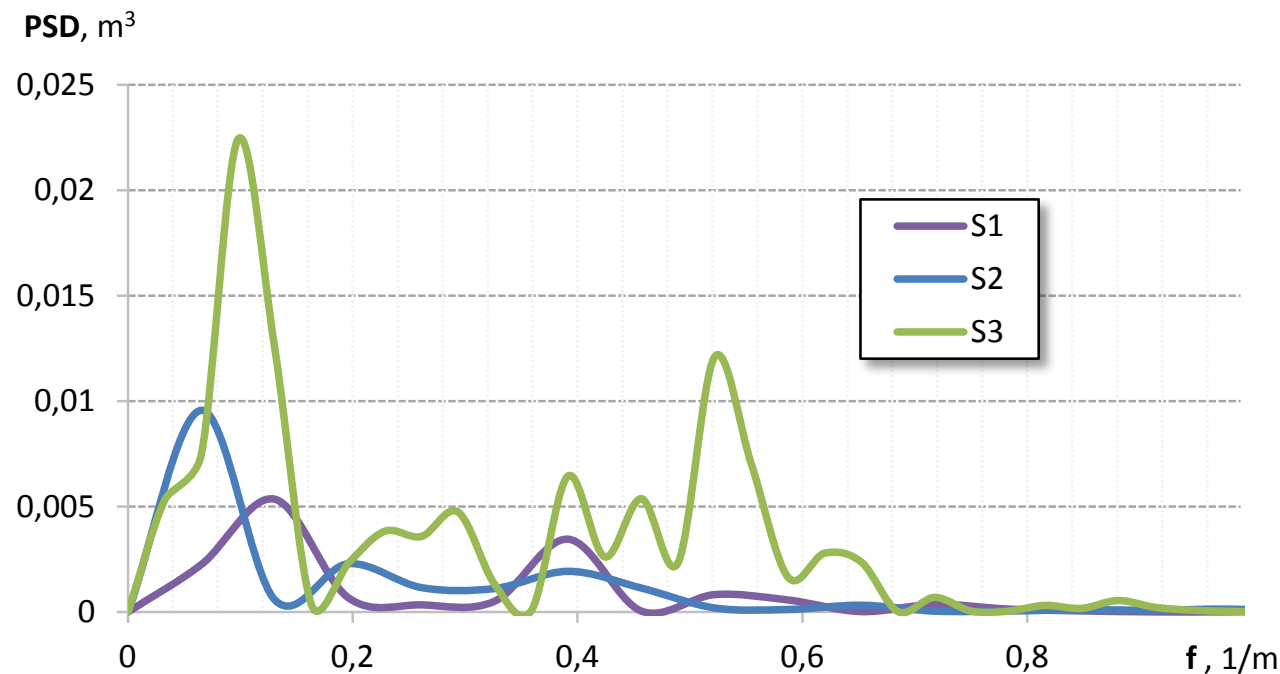

Rys. 8. Zestawienie charakterystyk gęstości widmowej mocy wymuszenia kinematycznego kót pojazdu podczas jazdy po badanych odcinkach dróg poligonowych z prędkościq $V=12 \mathrm{~km} / \mathrm{h}$

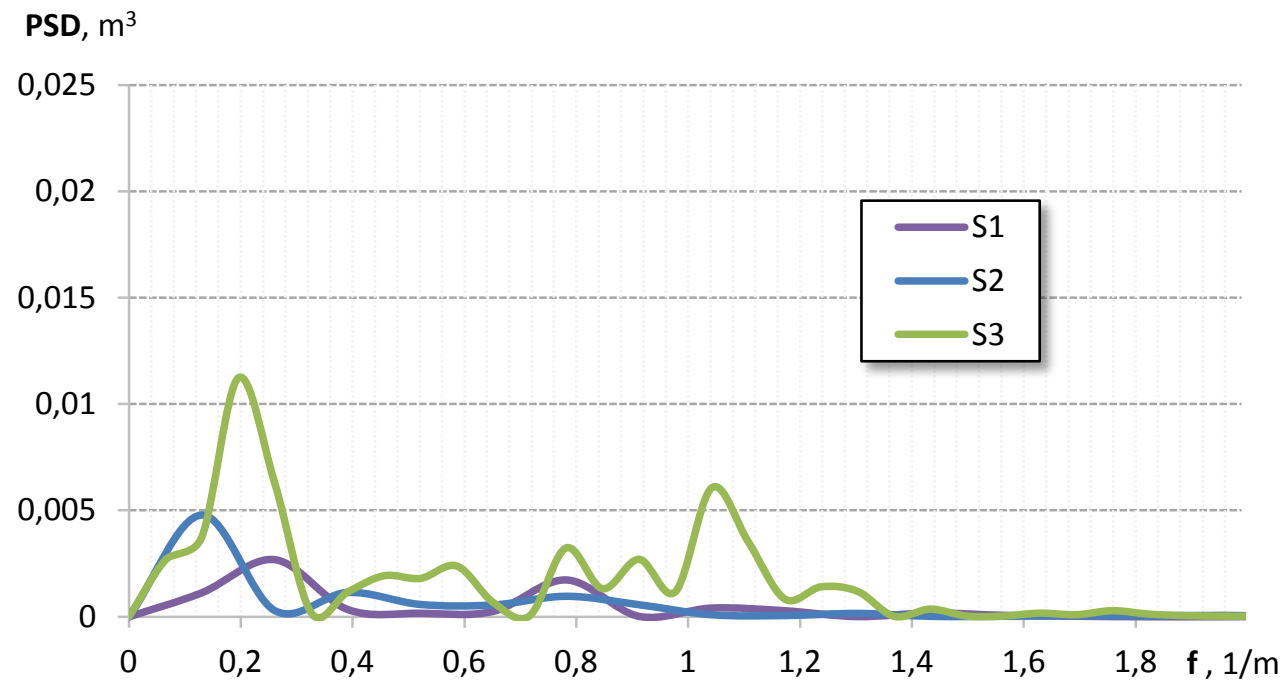

Rys. 9. Zestawienie charakterystyk gęstości widmowej mocy wymuszenia kinematycznego kót pojazdu podczas jazdy po badanych odcinkach dróg poligonowych z prędkościa $V=24 \mathrm{~km} / \mathrm{h}$ 
Geometrical analysis of profile of certain heavy terrain sections....

Analiza geometrii profilu wybranych odcinków dróg poligonowych....

Wyniki pomiaru bezpośredniego wykazały podobne wartości skuteczne RMS odcinków dróg poligonowych S1 i S2 mimo, że na podstawie oceny wzrokowej podłoże S2 ma znacznie wyższe amplitudy nierówności od podłoża S1. (tab. 1, rys. 2). $\mathrm{Na}$ charakterystykach widmowych widać, że podłoże na odcinku S2 ma wyraźnie wyższą składową harmoniczną zmian nierówności profilu w porównaniu z podłożem odcinka S1 w zakresie wartości częstotliwości drogowej do ok $0.051 / \mathrm{m}$. W tym zakresie częstotliwości drogowej długość nierówności przekracza 20m.

Zatem ich wpływ na poziom obciążeń dynamicznych elementów układu jezdnego jest znikomy, szczególnie podczas jazdy z małą prędkością, typową dla ruchu w warunkach terenowych. Natomiast odcinek drogi poligonowej S1 charakteryzują wyraźnie wyższe wartości charakterystyk widmowych w porównaniu z drogą S2 w zakresie wyższych częstotliwości drogowych (np. przy około 0.12, 0.16 i $0.221 / \mathrm{m})$. Zatem w profilu drogi $\mathrm{S} 1$ występuje szereg krótszych nierówności o długości do około 4.5m o amplitudzie wyższej niż w profilu drogi S2. W efekcie uzasadniony jest opisywany przypadek, gdy przy porównywalnych wartościach skutecznych RMS przebiegu zmian wysokości profilu obu porównywanych odcinków drogi, wymuszenia kinematyczne kół jezdnych pojazdu różnią się pod względem wartości amplitudy i częstotliwości.

Odcinek drogi poligonowej S3 charakteryzuje znacznie wyższa skuteczna RMS zmian wysokości profilu w porównaniu $\mathrm{z}$ innymi odcinkami dróg. Jednak w tym przypadku najwyższe wartości amplitudy zmian wysokości profilu są wyższe od amplitud uzyskanych na pozostałych podłożach zarówno w zakresie najniższych jak i najwyższych wartości analizowanych częstotliwości drogowych.

Wyznaczone charakterystyki profilu wybranych odcinków dróg poligonowych wykazały, że podłoża gruntowe są podłożami specyficznymi. Z puntu widzenia długości nierówności (do ok. $0.31 / \mathrm{m}$ ) są to podłoża, które w klasyfikacji podłoży drogowych utwardzonych są uznawane za podłoża wyrównane ,uneveness" [5]. Zatem trzeba było uznać te podłoża jako podłoża o najwyższej jakości. Jednak podłoża gruntowe charakteryzują znacznie większe wartości amplitudy zmian ich profilu niż dróg utwardzonych dobrej jakości. Zatem podłoża gruntowe nie powinny być oceniane takimi kryteriami klasyfikacji jak drogi utwardzone.

Wszystkie badane odcinki dróg poligonowych wywołują drgania kół jezdnych o niskich częstotliwościach podczas jazdy $\mathrm{z}$ prędkościami możliwymi do rozwinięcia w warunkach terenowych (rys. 6-9). Zasadnicza część mocy drgań kół jezdnych pojazdu wynikająca $\mathrm{z}$ częstotliwości wymuszenia kinematycznego w postaci nierówności podłoża mieści się zakresie częstotliwości $\mathrm{f}=0.7 \mathrm{~Hz}$ podczas jazdy z prędkością $12 \mathrm{~km} / \mathrm{h}$ oraz $\mathrm{f}=1.4 \mathrm{~Hz}$ podczas jazdy z prędkością $24 \mathrm{~km} / \mathrm{h}$. Są to częstotliwości podrezonansowe $\mathrm{w}$ stosunku do częstotliwości drgań własnych nadwozia typowego samochodu terenowego (ok. $2 \mathrm{~Hz}$ ), a tym bardziej do częstotliwości drgań własnych osi jezdnych (od ok. 8 do 10Hz) w ruchu pionowym. 


\section{Podsumowanie}

Wyniki badań niosą ze sobą wiedzę w zakresie właściwości geometrycznych dróg poligonowych, w tym struktury częstotliwościowej wymuszenia kinematycznego drgań pionowych pojazdu podczas jazdy pojazdu w warunkach terenowych. Stanowią również źródło danych niezbędnych do badań symulacyjnych pojazdów podczas jazdy w warunkach terenowych.

Wyniki badań są przydatne w kontekście ustalenia lub określenia warunków badań przebiegiem pojazdów specjalnych w szczególności pojazdów wojskowych. Autorzy widzą możliwość zastosowania wyników w dalszych badaniach ukierunkowanych na opis i klasyfikację poligonowych odcinków badawczych. Scharakteryzowanie poszczególnych odcinków badawczych umożliwi planowanie struktury i zakresu badań przebiegowych pojazdów w procesie badań kwalifikacyjnych.

Wyniki badań pokazały, że wartość skuteczna RMS zmian wysokości profilu drogi, często stosowana jako wskaźnik porównawczy, nie zapewnia w pełni trafnego porównania dróg poligonowych jako źródła drgań i udarów elementów układu jezdnego pojazdu podczas jazdy w warunkach terenowych. Istotnym elementem charakterystyki profilu dróg gruntowych jest struktura częstotliwościowa ich nierówności.

\section{Literatura}

[1] Endurance testing of tracked and wheeled vehicles. U.S. Army Test and Evaluation Command, Aberdeen Proving Ground, Maryland, 26 June 81, ADA102 584.

[2] Dawkins J. J.: Terrain Characterization and Roughness Estimation for Simulation and Control of Unmanned Ground Vehicles. Auburn, Alabama 2011.

[3] Jacenko N.: Drgania, wytrzymałość i przyspieszone badania samochodów ciężarowych. WKit, Warszawa 1975.

[4] Johannesson P., Podgórski K.: Modelling roughness of road profiles on parallel tracks using roughness indicators. Matematiska vetenskaper 2014.

[5] Loprencipe G., Cantisani G.: Unified Analysis of Road Pavement Profiles for Evaluation of Surface Characteristics. Modern Applied Science; Vol. 7, No. 8; 2013, ISSN 1913-1844 E-ISSN 1913-1852, Published by Canadian Center of Science and Education.

[6] Ojeda L., Borenstein J.: Terrain Characterization and Classification with a Mobile Robot. Journal of Field Robotics 2006. 
Geometrical analysis of profile of certain heavy terrain sections....

Analiza geometrii profilu wybranych odcinków dróg poligonowych....

[7] Patel C. B., Gohil P. P.: Modelling and vibration analysis of a road profile measuring system. International Journal of Automotive and Mechanical Engineering 2010.

[8] Test Operations Procedure (TOP) 01-1-011A Vehicle Test Facilities at Aberdeen Test Center and Yuma Test Center. US Army Aberdeen Test Center, Aberdeen Proving Ground, MD, 27-02-2012.

[9] Kasprzak T., Prochowski L.: Obciążenia dynamiczne zawieszeń, WKiŁ, Warszawa 1990.

[10] Mitschke M.: Dynamika samochodu, WKiŁ, Warszawa 1977.

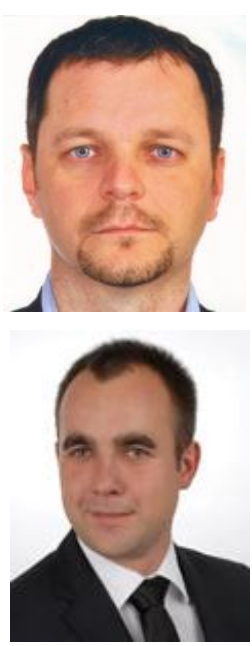

dr inj. Witold Luty Wojskowy Instytut Techniki Pancernej $i$ Samochodowej, Zakład Pojazdów Kołowych Laboratorium Bojowych Wozów Opancerzonych

mgr inż. Marcin Mieteń Wojskowy Instytut Techniki Pancernej $i$ Samochodowej Zakład Pojazdów Kolowych Laboratorium Bojowych Wozów Opancerzonych 